\title{
ANALISIS SISTEM INFORMASI AKUNTANSI PENJUALAN DAN PENERIMAAN KAS DALAM MENINGKATKAN PENGENDALIAN INTERN \\ ( Studi Kasus PT Putra Indo Cahaya Batam ) \\ SALES ACCOUNTING INFORMATION SYSTEM ANALYSIS AND ADMISSION OF CASH IN IMPROVING INTERNAL CONTROL (Case Study of PT Putra Indo Cahaya Batam)
}

\author{
Hendry jaya ${ }^{1}$ \\ ${ }^{1}$ (Akuntansi, Ekonomi, Universitas Riau Kepulauan, Indonesia) \\ jayahendry@yahoo.com ${ }^{1}$
}

\begin{abstract}
ABSTRAK
Latar belakang penelitian ini adalah fakta yang menunjukkan hal terpenting dalam kegiatan operasi perusahaan adalah penjualan dan penerimaan kas. Sistem informasi akuntansi penjualan dan penerimaan kas adalah salah satu sub sistem dalam informasi akuntansi yang menjelaskan tentang bagaimana prosedur yang benar dalam aktivitas penjualan dan penerimaan kas. Itu juga ada dalam sistem pengendalian internal yang juga membutuhkan seperangkat sistem kontrol yang dapat melindungi sistem itu dari penipuan, baik itu manipulasi data atau inventaris. Permasalahan dalam penelitian ini adalah (1) Bagaimana penerapan sistem informasi penjualan dan penerimaan kas di PT Putra Indo Cahaya Batam? Penelitian ini menggunakan pendekatan kualitatif karena data yang dikumpulkan berupa pernyataan atau deskriptif yang diterima oleh penulis.Data yang digunakan dalam penelitian ini adalah data primer. Prosedur pengumpulan data adalah observasi, dokumentasi dan wawancara langsung ke objek penelitian. Kesimpulan dari penelitian ini adalah penerapan sistem informasi akuntansi dalam penjualan tunai dan penerimaan kas di PT Putra Indo Cahaya Batam masih kurang baik terlihat dari adanya fungsi ganda, yaitu fungsi pengiriman yang ganda sebagai fungsi gudang dan kurangnya data dan kelengkapan dokumen yang digunakan dalam penjualan tunai dan penerimaan kas.Analisis sistem informasi akuntansi penjualan tunai dan penerimaan kas dalam pengendalian internal di PT Putra Indo Cahaya Batam masih kurang baik dan lemah karena tidak ada cap yang dilunasi dalam tagihan dari fungsi tunai atau fungsi pengiriman, dan jumlah penerimaan kas dari penjualan tunai disetorkan ke bank pada hari ketiga bukan pada hari transaksi terjadi atau hari berikutnya, itu menyebabkan penyalahgunaan dan pengalihan kas. Kemudian, juga tidak ada pengecekan saldo kas dan cash opname secara berkala atau tiba-tiba oleh kontrol internal.
\end{abstract}




\begin{abstract}
The background of this research is the fact that shown the most important things in operating activity of corporate are sales and cash receipt. Sales accounting and cash receipt information system is the one of the sub-system in accounting information which explain on how the right procedure in selling and cash receipt activity. It also exist in internal controlling system that also need a set of control system which can protect that system from fraud, whether the manipulation of data or inventory. The problem of this research is (1) How the implementation of information system of sales and cash receipt in PT Putra Indo Cahaya Batam? The research use qualitative approach because the data that were collected in form of statement or descriptive received by the author.The data the use in this research is primary data. The data collection procedure are observation, documentation and direct interview to the object of research. The the conclusion of this research is the implementation of accounting information system in cash sales and cash receipt in PT Putra Indo Cahaya Batam it's still not good it looks from the existence of double function, that are the shipping function are double as warehouse function and lack of data and document completeness that use in cash sales and cash receipt.Accounting information system analysis of cash sales and cash receipt in the internal control at in PT Putra Indo Cahaya Batam stil not good and weak cause there is no stamp paid off in the invoice from cash function or shipping function, and the amount of cash receipt from cash sales deposited to the bank in the third days not in day the transaction happen or next day, it's cause misuse and cash diversion. Then, also there is no checking cash balance and cash opname periodically or suddenly by the internal control.
\end{abstract}

Keywords: accounting information system, sales, cash receipt, internal control. 


\section{PENDAHULUAN}

\section{Latar Belakang Masalah}

Perkembangan teknologi informasi sangat dibutuhkan oleh seluruh perusahaanterutama bagi perusahaan yang sedang berkembang.Seperti pada saat sekarang ini semua sektor memasuki kehidupan masyarakat, tak dapat kita pungkiri itu semua merambat keseluruh sektor tanpa kecuali pada perusahaan.Apalagi dengan adanya kompetisi global yang mendorong persaingan ketat diantara perusahaan, sehingga perusahaan harus mengelola perusahaannya dengan baik agar tujuan bisa tercapai.Perkembangan dunia usaha yang semakin luas saat ini menuntut adanya perkembangan sistem akuntansi baru untuk memenuhi kebutuhan informasi yang lebih baik.Kebutuhan informasi ini ditandai dengan penggunaan komputer dalam perkembangan teknologi informasi.

Perangkat komputer merupakan salah satu alat yang digunakan untuk mengelola data menjadi infomasi yang diharapkan.Komputer mengalami perkembangan yang signifikan pada masa sekarang, mulai dari teknologi perangkat keras (hardware) maupun perangkat lunak (software).Selain itu, perangkat komputer juga sudah semakin banyak dimanfaatkan terutama oleh dunia usaha dalam hal pengelolaan data dan informasi transaksi bisnisnya.Perusahaan membutuhkan keberadaankomputer sebab informasi yang diperoleh dapat menjadi pedoman penting ketika perusahaan akan mengambil keputusan.
Keberadaan perangkat komputer mendukung adanya implementasi sistem informasi khususnya dalam perusahaan/bisnis.

PT Putra Indo Cahaya merupakan perusahaan di bidang distributor tas, perusahaan ini telah berdiri kurang lebih selama hampir 10 tahun. Tas pada umumnya sangat diminati, beberapa merek produk terbaik kami yang laris terjual adalah Guccy, Lenore, Michell Jacob, Charles and kaith dan tas fashionfashion lainnya yang sangat digemari dikalangan masyarakat. Berikut data penjualan Tas yang terhitung dari tahun 2015,2016,2017.

\section{NERACA Saldo PT Pura Indo Cahaya Batam}

\begin{tabular}{|l|l|l|c|l|l|}
\hline \multicolumn{2}{|l|}{ Aktiva : } & \multicolumn{2}{l|}{ Pasiva : } \\
\hline $\begin{array}{c}\text { No. } \\
\text { Akun }\end{array}$ & Keterangan & Jumlah & $\begin{array}{l}\text { No } \\
\text { Akun }\end{array}$ & Keterangan & Jumlah \\
\hline 101 & $\begin{array}{l}\text { Kas } \\
\text { Perusahan }\end{array}$ & 1.232 .000 .000 & 201 & $\begin{array}{l}\text { Hutang } \\
\text { Dagang }\end{array}$ & 450.000 .000 \\
\hline 102 & $\begin{array}{l}\text { Persediaan } \\
\text { Barang } \\
\text { Dagang }\end{array}$ & - & 202 & $\begin{array}{l}\text { Hutang } \\
\text { Wesel }\end{array}$ & - \\
\hline 103 & $\begin{array}{l}\text { Piutang } \\
\text { Dagang }\end{array}$ & -750.000 .000 & 300 & Modal & 1.500 .000 .000 \\
\hline 111 & $\begin{array}{l}\text { Peralatan } \\
\text { Kantor }\end{array}$ & - & 301 & Prive & - \\
\hline 112 & $\begin{array}{l}\text { Akm.Penyusu } \\
\text { tan Peralatan } \\
\text { Kantor }\end{array}$ & 5.000 .000 & 313 & Laba/Rugi & 37.000 .000 \\
\hline & Jumlah & $1.987 . .000 .000$ & & $\begin{array}{l}\text { Jumlah } \\
\text { Pasiva }\end{array}$ & 1.987 .000 .000 \\
\hline
\end{tabular}

Berdasarkan hal tersebut diatas, penulis tertarik untuk meneliti dengan judul "Analisis Sistem Informasi Akuntansi Penjualan dan Penerimaan Kas dalam Meningkatkan Pengendalian Intern pada PT Putra Indo Cahaya Batam."

\section{Batasan Masalah}

Berdasarkan latar belakang yang telah di uraikan maka penulis hanya membataskan permasalahan pada dua variable sistem informasi akuntansi 
penjualan dan penerimaan kas dalam meningkatkan pengendalian intern perusahaan pada PT Putra Indo Cahaya Batam.

\section{Rumusan Masalah}

Berdasarkan uraian latar belakang tersebut, maka perumusan masalah yang akan dibahas adalah sebagai berikut:

Bagaimana Penerapan sistem informasi akuntansi penjualan dan penerimaan kas dalam meningkatkan pengendalian intern di PT Putra Indo Cahaya Batam ?

\section{Tujuan Penelitian}

Penelitian yang dilakukan penulis ini bertujuan untuk mengetahui Bagaimana Penerapan sistem informasi akuntansi penjualan dan penerimaan kas dalam meningkatkan pengendalian intern yang digunakan di PT Putra Indo Cahaya Batam.

\section{Manfaat Penelitian}

Adapun manfaat yang diharapkan adalah:

1.Hasil penelitian ini diharapkan dapat memberikan sumbangan bagi ilmu pengetahuan dan pendidikan dan diharapkan dapat menjadi bahan referensi dalam melakukan penelitian dengan objek atupun masalah yang sama dimasa yang akan datang maupun untuk penelitian lanjutan.

\section{Bagi Penulis}

Penelitian ini diharapkan menambah pengetahuan mengenai sistem informasi akuntansi penjualan dan penerimaan kas dalam meningkatkan pengendalian intern pada PT Putra Indo Cahya Batam.

\section{TINJAUAN PUSTAKA \\ Pengertian Sistem}

Sistem adalah suatu kerangka dari prosedur-prosedur yang saling berhubungan yang disusun sesuai dengan suatu skema yang menyeluruh untuk melaksanakan suatu kegiatan atau fungsi utama dari suatu perushaan.

Jadi dari defenisi-defenisi diatas dapat disimpulkan bahwa sistem harus mengarah ke satu atau beberapa tujuan yang dapat memberikan ukuran waktu atau informasi, maka dari sistem tersebut harus tetap mengarah ke satu tujuan.Jika sebuah sistem tidak lagi mengarah ke sebuah tujuan, maka sistem itu harus diganti.

\section{Pengertian Informasi}

Menurut Laudon dan laudon (2010) mengatakan bahwa sistem informasi akuntansi adalah : suatu komponen yang saling bekerja satu sama lain untuk mengumpulkan, mengolah, menyimpan dan juga menyebarkan informasi untuk mendukung suatu kegiatan suatu organisasi seperti pengambilan keputusan,koordinasi,pengendalian. Informasi merupakan hasil pengolahan data sehingga menjadi bentuk yang penting bagi penerimanya dan mempunyai kegunaan sebagai dasar dalam pengambilan keputusan yang dapat dirasakan akibatnya secara langsung saat itu juga atau secara tidak langsung pada saat mendatang. 


\section{Pengertian Akuntansi}

Sujarweni (2015), akuntansi adalah proses dari transaksi yang dibuktikan dengan faktur, lalu dari transaksi dibuat jurnal, buku besar, neraca lajur, kemudian akan menghasilkan informasi dalam bentuk laporan keuangan yang digunakan pihak-pihak tertentu.

\section{Pengertian Sistem Informasi Akuntansi}

Sistem informasi akuntansi adalah : sistem akuntansi berbasis komputerisasi yang mengolah data keuangan yang berhubungan dengan data transaksi dalam siklus akuntansi dan menyajikannya dalam bentuk laporan keuangan kepada manajemen perusahaan.

Jadi dari data diatas dapat disimpulkan bahwa system informasi akuntansi adalah kumpulan sumber daya, seperti manusia dan peralatan, yang dirancang untuk mengubah data keuangan dan data lainnya kedalam informasi.Informasi tersebut dikomunikasikan kepada para pembuat keputusan. Sistem informasi akuntansi dapat dilakukan dengan 2 macam cara, yaitu sistem manual atau melalui system terkomputerisasi.

\section{Fungsi Sistem Informasi}

\section{Akuntansi}

Bagi suatu perusahaan, sistem informasi akuntansi dibangun dengan tujuan utama untuk mengolah data akuntansi yang berasal dari berbagai sumber menjadi informasi akuntansi yang diperlukan oleh berbagai macam pemakai untuk mengurangi resiko saat mengambil keputusan.

\section{Unsur-unsur Sistem Informasi} Akutansi

Menurut Mulyadi (2013:3) terdapat lima unsur pokok dalam sistem akuntansi, yaitu :

1. Formulir

Formulir merupakan dokumen yang digunakan untuk merekam terjadinya transaksi.Formulir sering disebut dengan istilah dokumen karena dengan formulir ini peristiwa yang terjadi dalam organisasi direkam (didokumentasikan) di atas secarik kertas.Contoh formulir adalah faktur penjualan, bukti kas keluar, cek, dan lain-lain.

2. Jurnal

Jurnal merupakan catatan akuntansi pertama yang digunakan untuk mencatat, mengklasifikasikan, dan meringkas data keuangan dan data lainnya.Contoh jurnal adalah jurnal pembelian, jurnal penjualan, jurnal penerimaan kas, dan lain-lain.

3. Buku Besar

Buku besar (general ledger) terdiri dari rekening-rekening yang digunakan untuk meringkas data keuangan yang telah dicatat sebelumnya dalam jurnal. Rekening-rekening tersebut disediakan sesuai dengan unsurunsur informasi yang akan disajikan dalam laporan keuangan. 
4. Buku pembantu terdiri dari rekening-rekening pembantu yang merinci data keuangan yang tercantum dalam rekening tertentu dalam buku besar. Sebagai contoh buku pembantu piutang yang merinci semua data tentang debitur.

5. Laporan Hasil akhir dari proses akuntansi adalah laporan keuangan yang dapat berupa laporan laba/rugi, laporan perubahan modal, laporan harga pokok produksi, dan lain-lain.

\section{Kualitas Data Sistem Informasi Akuntansi}

Seperti telah disebutkan di atas bahwa kualitas informasi merupakan hal yang sangat penting dalam sistem informasi

Menurut Mulyadi (2008:202), "Penjualan merupakan kegiatan yang dilakukan oleh penjual dalam menjual barang atau jasa dengan harapan akan memperoleh laba dari adanya transaksi-transaksi tersebut dan penjualan dapat diartikan sebagai pengalihan atau pemindahan hak kepemilikan atas barang atau jasa dari pihak penjual ke pembeli.

\section{Prosedur Penjualan}

1. Prosedur Penjualan Tunai

Berikut ini adalah penjelasan untuk Prosedur Penjualan Tunai yang dinyatakan oleh Mulyadi (2013) adalah sebagai berikut :

a) Bagian Order Penjualan

Menerima order dari pembeli lalu membuat faktur penjualan tunai rangkap tiga. Lembar pertama untuk diserahkan ke bagian kasa, lembar kedua untuk tembusan ke bagian gudang pada saat pengiriman dan lembar ketiga untuk disimpan oleh perusahaan.

b) Bagian Kas

Menerima faktur penjualan tunai untu mengetahui

berapa harga yang harus diterima dari pembeli dan menerima uang tunai dari pembeli sesuai dengan yang tertulis di lembar faktur penjualan tunai. Bagian kasa mengoprasikan register kas untuk mendapatkan pita register yang akan digunakan sebagai bukti penerimaan kas.

c) Bagian Gudang

Bagian gudang menerima faktur penjualan sebagai informasi barang apa saja yang telah diorder. Mencatat pengurangan pada persediaan di kartu gudang dan memberikan barang yang di order oleh pembeli bersamaan dengan faktur penjualan tunai ke bagian pengiriman barang.

d) Bagian Pengiriman

Bagian pengiriman menerima faktur penjualan tunai dan pita register kas dari bagian kasa untuk bukti bahwa pembeli telah melakukan pembayaran secara tunai serta menerima faktur penjualan tunai lembar kedua dari bagian gudang, hal tersebut untuk mencocokan dari kedua bagian tersebut. Setelah keduanya cocok, bagian pengiriman memberikan barang yang di order oleh pembeli beserta faktur penjualan tunai lembar kedua. 
e) Bagian Jurnal

Menerima faktur penjualan tunai lalu membuat jurnal pada jurnal penjualan, menerima bukti setoran bank untuk membuat jurnal pada jurnal penerimaan kas.

2. Prosedur Penjualan Kredit

Berikut ini adalah penjelasan untuk Prosedur Penjualan Kredit yang dinyatakan oleh Mulyadi(2013) adalah sebagai berikut :

a) Bagian Order Penjualan

Dalam prosedur ini fungsi penjualan menerima order dari pembeli dan menambahkan informasi penting pada surat order dari pembeli. Fungsi penjualan kemudian membuat faktur penjualan kartu kredit dan mengirimkannya kepada berbagai fungsi yang lain untuk memungkinkan fungsi tersebut memberikan kontribusi dalam melayani order dari pembeli.

b) Bagian Gudang

Dalam prosedur ini fungsi gudang menyiapkan barang yang telah di order oleh pelanggan/pembeli dan mempersiapkan penge-packan barang untuk barang tersebut di kirimkan oleh bagian pengiriman.

c) Bagian Pengiriman

Dalam prosedur ini fungsi pengiriman mengirimkan barang kepada pembeli sesuai dengan informasi yang tercantum dalam faktur penjualan kartu kredit yang diterima dari fungsi gudang.Pada saat penyerahan barang, fungsi pengiriman meminta tanda tangan penerimaan barang dari pemegang kartu kredit di atas faktur penjualan kartu kredit.

d) Bagian Pencatatan Piutang

Dalam prosedur ini fungsi akuntansi mencatat tembusan faktur penjualan kartu kredit kedalam kartu piutang.

e) Bagian Penagihan

Dalam prosedur ini fungsi penagihan menerima faktur penjualan kartu kredit dan mengarsipkannya menurut abjad. Secara periodik fungsi penagihan membuat surat tagihan dan mengirimkanya kepada pemegang kartu kredit perusahaan, dilampiri dengan faktur penjualan kartu kredit.

f) Bagian Pencatatan Penjualan Dalam prosedur ini fungsi akuntansi mencatat transaksi penjualan kartu kredit ke dalam jurnal penjualan.

\section{Pengertian Sistem Informasi Akuntansi Penjualan}

Menurut Mulyadi (2010:205) menyatakan bahwa Sistem Informasi Akuntansi Penjualan adalah : Suatu sistem informasi yang mengorganisasikan serangkaian prosedur dan metode yang dirancang untuk menghasilkan, menganalisa, menyebarkan dan memperoleh informasi guna mendukung 
pengambilan keputusan mengenai penjualan.

\section{Pengertian Penerimaan Kas}

Menurut Mulyadi (2010)

Penerimaan kas perusahaan berasal dari dua sumber utama, penerimaan kas dari penjualan tunai dan penerimaan kas dari piutang.Sumber penerimaan kas terbesar suatu perusahaan dagang berasal dari transaksi penjualan tunai.

\section{Pengertian Sitem Pengendalian Intern}

Menurut Harnanto dalam Nugroho (2009) menyatakan bahwa sistem pengendalian intern adalah suatu tipe pengawasan yang dirancang dengan diintegrasikan ke dalam sistem pembagian atau pendelegasian tugas, tanggung jawab, wewenang dalam organisasi perusahaan.

\section{Tujuan Sitem Pengendalian Intern}

Tujuan Pengendalian Intern menurut Mulyadi (2013) adalah sebagai berikut:

1. Menjaga kekayaan dan catatan organisasi.

Adanya pengendalian intern yang memadai maka akan menjaga agar kekayaan perusahaan secara fisik maupun non fisik tidak rawan untuk dicuri, disalah gunakan atau dihancurkan.

2. Mengecek ketelitian dan keandala akuntansi.

Pengendalian intern dirancang untuk memberikan jaminan proses pengolahan data akuntansi yang akan menghasilkan informasi keuangan yang teliti dan andal.

\section{KERANGAKA PEMIKIRAN}

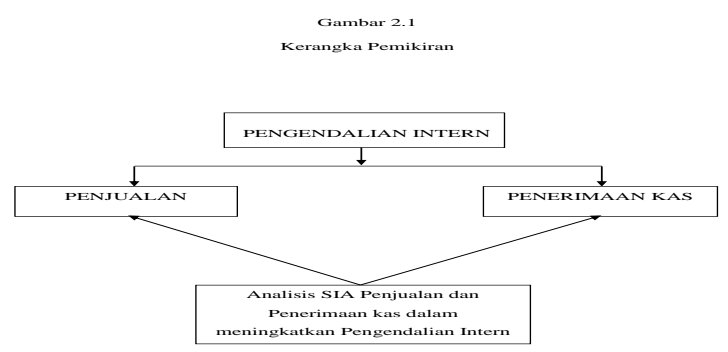

\section{METODOLOGI PENELITIAN}

\section{Jenis Penelitian}

Jenis penelitian yang digunakan dalam penelitian ini adalah metode penelitian deskriptif dan penelitian kualitatif. Penelitian ini tergolong pada penelitian deskriptif dengan menggunakan pendekatan kualitatif

\section{Metode Pengumpulan Data}

1) Interview (wawancara)

\section{Dalam}

penelitian ini wawancara digunakan untuk mengadakan tanya jawab langsung dengan pimpinan dan karyawan perusahaanyang bersangkutan tentang hal-hal yang berhubungan dengan bidang yang diteliti dalam penelitian.

2) Studi pustaka

Metode pengumpulan data yang diarahkan kepada pencarian data dan informasi melalui dokumen-dokumen, baik dokumen tertulis, fotofoto, gambar, maupun dokumen elektronik yang 
dapat mendukung dalam proses penulisan.

3) Observasi

Melakukan pengamatan pada objek yang diteliti yang berhubungan dengan topik pembahasaan penelitian dan untuk mengetahui sejarah perusahaan, struktur organisasi perusahaan, wewenang dan tanggung jawab masing-masing bagian organisasi perusahaan yang melibatkan proses penjualan dan penerimaan kas.

4) Dokumentasi

Data yang diharapkan diperoleh dari dokumentasi ini adalah mengenai struktur organisasi, dan prosedur penjualan dan penerimaan kas.

\section{Teknik Analisa Data}

Teknik yang digunakan dalam penelitian ini adalah analisis diskriptif komperatif dengan cara mendiskripsikan atau menggambarkan keadaan obyek penelitian yang sesungguhnya untuk mengetahui dan menganalisis tentang permasalahan yang dihadapi oleh obyek penelitian kemudian dibandingkan dengan standar yang ada pada saat itu untuk selanjutnya di deskripsikan bagaimana PT Putra Indo Cahaya Batam memberlakukan perihal yang berkaitan dengan Penjualan dan Penerimaan kas dalam meningkatkan Pengendalian Intern.

\section{HASIL PENELITIAN DAN PEMBAHASAN}

Fungsi-Fungsi yang Terkait dari Penjualan Tunai yang ada pada PT Putra Indo Cahaya Batam.

1.Fungsi penjualan, bertugas menerima order dari pelanggan dan melakukan pendataan pesanan yang diminta pelanggan dan sebagai pengatur penjualan barang serta membuat laporan penjualan.

2.Fungsi Gudang, bertugas untuk menyiapkan barang yang dipesan oleh pembeli, mencatat keluar masuknya barang dagangan dan menyerahkan barang yang dipesan pelanggan ke fungsi pengiriman, disini fungsi pengiriman barang juga dirangkap oleh bagian fungsi gudang.

3.Fungsi Akuntansi, bertugas sebagai pencatat transaksi penjualan dan membuat laporan keuangan yang berasal dari laporan penjualan.

Fungsi yang terkait dari Penjualan Kredit yang ada pada PT Putra Indo Cahaya Batam:

1. Fungsi Penjualan, bertugas untuk menerima order dari pelanggan, mengedit order dari pelanggan, meminta otorisasi kredit, menentukan tanggal pengiriman barang.

2. Fungsi Gudang, bertugas untuk menyimpan dan menyiapkan barang yang dipesan oleh pelanggan serta menyerahkan barang ke bagian pengiriman, 
disini fungsi pengiriman barang juga dirangkap oleh bagian fungsi gudang yang bertugas untuk menyerahkan barang atas dasar surat order pengiriman yang diterima dari fungsi penjualan.

3. Fungsi Akuntansi, bertugas untuk mencatat transaksi penjualan kredit, membuat serta mengirimkan pernyataan piutang kepada debitur, dan membuat laporan keuangan dari laporan penjualan

Jaringan prosedur yang membentuk sistem penjualan ada di PT Putra Indo Cahaya Batam adalah

1) Prosedur Order Penjualan

Dalam prosedur ini fungsi penjualan menerima order dari pembeli, dalam perusahaan PT Putra Indo Cahaya Batam fungsi penjualan yaitu sales. Jadi yang menerima order dari pembeli dilakukan oleh sales dan yang membuat faktur penjulan tunai yaitu bagian admin penjualan.

2) Prosedur Pengambilan Barang

3) Dalam prosedur ini fungsi gudang untuk menyiapkan barang yang dipesan oleh pembeli mencatat keluar masuknya barang dagangan dan menyerahkan barang yang dipesan pelanggan ke fungsi pengiriman.

4) Prosedur Pengiriman Barang Dalam prosedur ini fungsi pengiriman menyerahkan barang kepada pembeli yang sudah di siapkan pada bagian gudang, dan menerima pembayaran dari pembeli yang akan diserahkan ke bagian finance. Dalam prosedur pengiriman barang ini dirangkap oleh fungsi gudang.

5) Prosedur Pencatatan Penjualan

Dalam prosedur ini fungsi akuntansi mencatat tansaksi penjualan tunai kedalam jurnal penjualan.

Prosedur yang membentuk Penjualan Kredit pada PT Putra Indo Cahaya Batam :

1. Prosedur Penjualan

Dalam prosedur ini fungsi penjualan menerima order dari pembeli dan menambahkan informasi penting pada surat order dari pembeli. Fungsi penjualan kemudian membuat faktur penjualan kredit dan mengirimkannya kepada berbagi fungsi yang lain untuk memungkinkan fungsi tersebut memberikan kontribusinya dalam melayani order dari pembeli.

2. Prosedur Pengambilan Barang Dalam prosedur ini fungsi gudang untuk menyiapkan barang yang dipesan oleh pembeli mencatat keluar masuknya barang dagangan dan menyerahkan barang yang dipesan pelanggan ke fungsi pengiriman. Disini fungsi 
pengiriman juga dirangkap oleh fungsi gudang.

3. Prosedur Pencatatan Piutang Dalam prosedur ini fungsi akuntansi mencatat tembusan faktur penjualan kredit kedalam surat piutang.

4. Prosedur Penagihan

Dalam prosedur ini fungsi penagihan menerima faktur penjualan kredit dan mengarsipkannya menurut abjad. Secara periodik fungsi penagihan membuat surat tagihan dan mengirimkannya kepada perusahaan, dilampiri dengan faktur penjualan kredit.

5.Pencatatan Penjualan

Dalam prosedur ini fungsi akuntansi mencatat tansaksi penjualan kredit kedalam jurnal penjualan.

\section{Dokumen-dokumen yang terkait}

1. Purchase Order

2. Faktur penjualan tunai (invoice)

Dokumen Penjualan Kredit pada PT Putra Indo Cahaya Batam :

1. Purchase Order

Purchase order dokumen yang dibuat oleh pembeli untuk menunjukkan barang yang ingin mereka beli dari PT Putra Indo Cahaya Batam. Purchase order ini berisi rincian penting tentangnama dan alamat perusahaan yang memesan barang tersebut, nama produk serta jumlah barang yang ingin dipesan.
2. Faktur Penjualan Kredit (Invoice)

Dalam bentuk invoice Penjualan kredit tertera syarat pembayaran dan tanggal jautuh tempo. Serta terdapat tiga rangkap (cofy) dengan warna yang berbeda dimana lembar pertama diberikan kepada pihak konsumen sementara lembar kedua kepada finance sebagai dokumen penagihan, dan untuk lembar ketiga akan dijadikan sebagai arship penjualan perusahaan yang disimpan berdasarkan no urut sebagai bahan pengendali yang apabila terjadi kejanggalan atau kekeliruan dalan transaksi penjualan.

3. Surat tanda Terima Barang Surat tanda terima barang diterbitkan sebagai bukti barang-barang yang telah dipesan telah diterima pembeli.Surat tanda terima barang dibuat hanya menggunakan nota jalan yang mengatakan bahwa barang tersebut sudah diterima.

\section{Catatan-catatan Akuntansi yang Digunakan pada PT Putra Indo Cahaya Batam.}

\section{A. Penjualan Tunai}

1. Jurnal Penjualan

Digunakan oleh fungsi kasir yang dipegang oleh finance untuk mencatat data penjualan.

2. Kartu Gudang 
Digunakan untuk mencatat berkurangnya kuantitas produk yang dijual atau keluar masuknya barang.

\section{B. Penjualan Kredit}

1. Jurnal Penjualan

Catatan akuntansi ini digunakan untuk mencatat transaksi penjualan, secara kredit.

2. Kartu Gudang

Catatan ini sebenarnya bukan termasuk dalam penggolongan catatan akuntansi.Catatan ini diselenggarakan oleh fungsi gudang dan hanya berisi data kuantitas barang yang disimpan di gudang beserta mutasinya.

\section{Fungsi-Fungsi yang Terkait}

A. Fungsi yang terkait dari Penerimaan Kas secara Tunai yang ada pada PT Putra Indo Cahaya Batam:

1. Fungsi Penjualan, bertugas menerima order dari pelanggan kemudian melakukan pendataan pesanan yang diminta pelanggan dan sebagai pengatur penjualan barang.

2. Fungsi Kasir, yang dipegang finance bertanggung jawab sebagai penerima kas dari pembeli dan mencatat transaksi jurnal penjualan,dan pembuatan laporan penjualan.
3. Fungsi Keuangan, bertanggung jawab sebagai pemengang keuangan baik penerimaan dan pengeluaran kas pada perusahaan. Fungsi tersebut dipegang oleh accounting.

4. Fungsi

Akuntansi,bertanggung

jawab sebagai pencatat transaksi penerimaan kas dan membuat laporan keuangan yang berasal dari laporan penjualan.

B. Fungsi yang terkait dari Penerimaan Kas secara Kredit yang ada pada PT Putra Indo Cahaya Batam:

1. Fungsi Penjualan, fungsi ini bertanggung jawab untuk meneliti status kredit pelanggan dan memberikan otorisasi pemberian kredit kepada pelanggan.

2. Fungsi Penangihan, fungsi ini bertanggung jawab membuat dan mengirimkan faktur penjualan kepada pelanggan. Fungsi penagihan dilakukan oleh bagian finance atau bagian keuangan secara langsung.

3. Fungsi Akuntansi, fungsi ini bertanggung jawab untuk mencatat piutang dari transaksi penjualan kredit, membuat serta mengirimkan pernyataan piutang kepada 
debitur, dan membuat laporan penjualan yang berasal dari laporan penjualan.

\section{Dokumen Penjualan Tunai}

1. Faktur Penjualan Tunai Faktur penjualan tunai di isi oleh fungsi penjualan yang berfungsi sebagai pengantar pembayaran oleh pembeli melalui bagian pengiriman kepada fungsi kas yaitu kasir dan sebagai dokumen sumber untuk pencatatan transaksi penjualan kedalam jurnal penjualan.

2. Bukti Setor Bank

Dokumen ini dibuat oleh fungsi kasir sebagai bukti penyetoran kas ke bank.Bukti setor bank oleh fungsi kasir dijadikan sebagai dokumen sumber untuk pencatatan transaksi penerimaan kas dari penjualan tunai ke dalam jurnal penerimaan kas.

\section{Dokumen Penjualan Kredit}

1. Surat tagihan

Surat tagihan ini merupakan dokumen yang isinya terdapat kode barang yang dipesan dan tanda terima dokumen tagihan kepada supplier dan dokumen yang sudah diterima oleh perusahaan. Surat tagihan terdapat dua rangkap, Lembar pertama diberikan kepada pelangan lembar kedua sebagai arsip kepada bagian penjualan.

2. Faktur Penjualan Kredit

Faktur penjualan kredit diisi oleh fungsi penjualan yang berfungsi sebagai pengantar pembayaran oleh pembeli melalui bagian pengiriman kepada fungsi kas yaitu kasir dan sebagai dokumen sumber untuk pencatatan transaksi penjualan kedalam jurnal penjualan.

3.Bukti Setor Bank

Dokumen ini dibuat oleh fungsi kasir sebagai bukti penyetoran kas yg diterima dari piutang ke bank, bersamaan dengan penyetoran kas dari piutang ke bank.

Catatan akuntansi yang terkait dengan penerimaan kas pada PT Putra Indo Cahaya Batam, yaitu:

1. Jurnal Penjualan

Digunakan oleh fungsi kasir untuk mencatat data penjualan.

2. Jurnal Penerimaan Kas Digunakan oleh fungsi kasir untuk mencatat data penerimaan kas dari penjualan tunai..

3. Kartu Gudang

Digunakan untuk mencatat berkurangnya kuantitas produk yang dijual atau keluar masuknya barang.

\section{Pengendalian Intern}

Pengendalian intern pada sistem akuntansi penjualan dan penerimaan kas pada PT Putra Indo Cahaya Batam sebagai berikut :
A. Organisasi 
Fungsi pengiriman barang tidak terpisah dengan Fungsi Gudang.Fungsi pengiriman seharunya terpisah oleh fungsi gudang dikarenakan bisa terjadinya kesalahan dalam pengiriman barang, kekurangan atau kelebihan kuantiti barang dan penumpukan tugas yang dikerjakan karena banyaknya pesanan dari konsumen. Dengan terpisahnya masingmasing fungsi tugas tersebut perusahaan dapat berjalan dengan baik sesuai dengan prosedur

B. Sistem Otorisasi dan Prosedur Pencatatan

1. Fungsi penjualan sudah terpisah dari fungsi kas.

2. Fungsi kas dipegang oleh Finance.

3. Transaksi penjualan tunai dilaksanakan oleh fungsi penjualan, fungsi kas, fungsi pengiriman.

4. Penerimaan order dari pembeli diotorisasi oleh fungsi penjualan dengan menggunakan surat order.

5. Penerimaan kas dari penjualan tunai diotorisasi oleh fungsi keuangan yaitu bagian finance. Invoice yang digunakan tidak membubuhkan cap "lunas" pada faktur penjualan tunai dan tidak ada penempelan pita register kas pada faktur tersebut.
6. Penyerahan barang diotorisasi oleh fungsi pengiriman sekaligus dirangkap oleh bagian gudang tetapi tidak membubuhkan cap "sudah diserahkan" pada faktur penjualan tunai.

7. Pencatatan ke dalam buku jurnal diotorisasi oleh fungsi Penjualan dan fungsi akuntansi .

C. Praktek yang sehat

1. Faktur penjualan tunai bernomor urut tercetak dan pemakainnya.

2. Jumlah kas yang diterima dari penjualan tunai disetor seluruhnya ke bank pada hari 3 hari sekali tidak pada hari yang sama dengan transaksi penjualan tunai atau hari kerja berikutnya.

3. Penghitungan saldo kas yang ada di tangan fungsi kas tidak secara periodik dan secara mendadak oleh fungsi pemeriksa intern.

D. Karyawan yang Kompeten

Dalam unsur karyawan kompeten, perusahaan memberlakukan untuk jurusan yang khusus dalam setiap fungsi.Karena karyawan yang berkompeten adalah karyawan yang memiliki kemampuan dalam kecakapan atau keterampilan dalam bidangnya.

\section{KESIMPULAN DAN SARAN Kesimpulan}


Dari hasil penelitian dan pembahasan analisis sistem informasi akuntansi penjualan dan penerimaan kas dalam meningkatkan pengendalian intern pada PT Putra Indo Cahaya Batam, maka dapat diambil kesimpulan sebagai berikut :

Pembagian tanggung jawab dalam organisasi pada PT Putra Indo Cahaya Batam masih belum sesuai, dikarenakan didalam struktur organisasi dalam penjualan dan penerimaan kas masih terdapat perangkapan fungsi,sehingga membuat pengendalian internal perusahaan belum sesuai dengan teori.

Catatan akuntansi yang digunakan penjualan dan penerimaan kas belum sesuai, dikarenakan catatan akuntansi yang digunakan penjualan tunai kurang terperinci atau kurang lengkap.Hanya ada 3 yang digunakan yaitu jurnal penjualan, jurnal penerimaan kas dan kartu gudang. Terdapat kurangnya kelengkapan dokumen yang digunakan penjualan tunai dan penerimaan kas, yaitu dokumen penerimaan kas dari penjualan tunai yang dilakukan yaitu faktur penjualan, dan bukti setor bank dan surat jalan yang menggunakan surat tanda terima barang dalam bentuk nota jalan.

Praktik yang sehat dalam pengendalian intern penjualan dan penerimaan kas masih belum sesuai dikarenakan jumlah kas yang diterima dari penjualan tunai disetor seluruhnya ke bank pada setiap 3 hari, tidak pada hari yang sama dengan transaksi penjualan tunai atau hari kerja berikutnya hal inilah yang akan menimbulkan penyalahgunaan dan penyelewengan kas.

\section{Saran}

Dari hasil kesimpulan diatas, maka saran-saran yang dapat diberikan untuk mengantisipasi permasalahan dalam sistem informasi akuntansi penjualan dan penerimaan kas yang ada adalah sebagai berikut :

1. Kas atau uang yang diterima dari customer, seharusnya disetorkan pada hari yang sama saat kas diterima atau selambatlambatnya pada waktu pagi hari kerja berikutnya, agar tidak terjadi penumpukan kas dan penyalahgunaan kas yang dapat merugikan perusahaan dan karyawannya.

2. Pemisahan fungsi kas dangan fungsi finance, sehingga fungsi kas hanya menerima pembayaran dari customer dan penyetoran kebank. Sedangkan untuk pencatatan sebaiknya dilakukan oleh karyawan lain, bisa dengan menambah karyawan baru khusus bagi pencatatan dan pembukuan atau diserahkan ke bagian administration dan finance coordinator.

3. Dokumen-dokumen seperti laporan penerimaan kas harian, dan pengiriman barant seharusnya diotorisasi oleh bagian yang sesuai dengan fungsinya masing-masing agar tidak terjadi penyalahgunaan wewenang dalam sistem 
akuntansi penerimaan kas pada PT Putra Indo Cahaya Batam.

4. Harus ada pembagian tugas yang jelas terhadap masing-masing bagian dalam organisasi agar pengendalian intern dapat tercapai dan sesuai dengan tujuan yang objektif.

DAFTAR PUSTAKA

Yos, Feto Daan 2009, Analisis Sisttem Informasi Akuntansi Penjualan Tunai untuk Meningkatkan Pengendalian Intern pada PT. Gendish Mitra Kinarya, Diakses 19 September 2013, dari http://gunadarma.ac.id/library /articles/ graduate/economy/2009/Arti kel_2120 5531.pdf

Silalahi, Rina 2008, Analisis Terhadap Sistem Informasi Akuntansi Penjualan dan Penerimaan Kas pada PT. Trubus Media Swadaya Medan, Diakses 30 September 2013, dari http://repository.usu.ac.id/sim plesearch

?query=sistem+informasi+ala t\&sort_by=0\&order=DESC\& $\mathrm{rpp}=10 \& \mathrm{etal}=0 \& \mathrm{~s}$ tart $=50$

AL Fatah. Hanif. 2007.Analisis dan Perancangan Sistem Informasi untuk Keunggulan Bersaing Perusahaan dan Organisasi Modern, Andi Offset, Yogyakarta.

Mardi. 2014.

SistemInformasiAkuntansi. Bogor:

Ghalia Indonesia.
Mulyadi.2008. Sistem Akuntansi, Salemba Empat, Yogyakarta.

Mulyadi. 2010.Sistem Akuntansi.

Edisi Ketiga. Jakarta :

Penerbit Salemba Empat.

Mulyadi.2009. Sistem Akuntansi, Salemba Empat, Yogyakarta.

Reeve, M. J. Warren. S. C. Duchac. E.

J. Wahyuni. T. E. Soepriyanto. G. 2009.

Pengantar

Akuntansi_Adaptasi

Indonesia. Penerbit Salemba Empat. Jakarta. 